Egbert Klautke

University College London, School of Slavonic and East European Studies

\title{
Urban history and modernity in Central Europe
}

Historiographical Review

The Historical Journal (2009/2010)

This historiographical review discusses recent literature on cities in modern Central Europe - mainly on Berlin and Vienna - which reflects the great variety of approaches to urban history and underlines the importance of urban history for the study of modernity. The history of urbanisation was a central event in the history of modernity. Especially in the Central European capitals of Berlin and Vienna, where modernisation and urban growth started later and then advanced quicker than in West European cities, all aspects of social, political, economic, and cultural modernity and its consequences can be observed in detail.

Urban history and the history of cities are thriving fields. While global history, international history and transnational history have attracted much attention in recent years in an effort to overcome the traditional fixation of historians on the nation-state, 'the city' as a topic has attracted historians more inconspicuously, without the clamour of theoretical debates. Well established as a sub-discipline, urban history is readily available as an alternative approach for historians who want to avoid the problems and limitations of national historiographies. In addition, it has benefited from the boom in cultural history; cities seem to be ideal objects via which to study 'high culture', popular culture, as well as everyday culture. But since urban history does not require a particular method or theory, social, economic, and political historians equally accept and practice it. More specifically, for students of modernity and modernism, cities are almost natural focal points, since the modern world in all its aspects - cultural, social, economic, political - was created in urban contexts; processes of urbanisation and modernistion overlap to a large degree. Hence historians of modernity 
become urban historians almost by default. A recent volume edited by Andreas Daum and Christof Mauch, dedicated to the comparative history of Washington D.C. and Berlin, demonstrates the range and scope of urban history well. ${ }^{1}$ While Daum tries to relate the study of 'capital cities' to the recent interests in both transnational and cultural history - based on his own work on Berlin, he stresses the symbolic, representative, and performative functions of capital cities $^{2}-$, the volume includes essays on the history of local government, the role of capital cities in a globalized world, on the perception of cities in travel literature, on architecture, everyday history, and the history of parks and gardens. By including social scientists and a literary critic, the volume also reminds us that cities as objects of study are by no means 'owned' by historians, but that urban studies are interdisciplinary by nature. The result of Daum and Mauch's volume, typically, is a mixed bag, with essays of different scope and quality. It does show clearly, though, that studying the history of cities can be rather complex, and that comparative studies of cities, even if only used as a heuristic tool, are highly desirable, while rarely practised. This historiographical review will discuss recent literature on cities in modern Central Europe mainly on Berlin and Vienna - which, on the whole, repeat this pattern, reflecting the great variety of approaches to urban history, and underlining the importance of urban history for the study of modernity.

II.

For a long time now, fin-de-siècle Vienna has been a favourite for scholars of modernism. In the wake of Carl E. Schorske's classic, a remarkable number of studies have been dedicated to the culture of a city that was home to Sigmund Freud and Ludwig Wittgenstein, Gustav Klimt and Egon Schiele, Arnold Schönberg and Gustav Mahler, Adolf Loos, Karl Kraus, and Hugo von Hofmannsthal.3 Especially in the 1980s, the view of 'Vienna 1900' as the

$1 \quad$ Andreas W. Daum, Christof Mauch, eds., Berlin - Washington, 180o200o. Capital Cities, Cultural Representations, and National Identities (Cambridge, 2005).

2 Andreas W. Daum, Kennedy in Berlin: Politik, Kultur und Emotionen im Kalten Krieg. Paderborn (Munich, 2003).

3 The most important studies are Carl E. Schorske, Politics and Culture; Fin-de-Siècle Vienna (London, 1980); Allan Janik and Stephen Toulmin, Wittgenstein's Vienna (London, 1973); Jacques Le Rider, Modernity and 
'birthplace of modernity' (Norman Stone) became almost a stereotype of its own, popularised by major exhibitions in Paris and New York, and adopted by the tourist industry in Vienna.4 So the stakes were high when Robert Weldon Whalen set out on the ambitious task of re-interpreting the cultural history of fin-de-siècle Vienna. 5 Whalen's main argument, however, which is meant to make most of the existing literature obsolete, is far-fetched and never convincing. He believes that 'modernism', at least in its Viennese variety, was at heart a religious phenomenon: 'Viennese modernism, I want to argue, was at root a religious phenomenon. It witnessed to what Paul Tillich would call a moment of "kairos", a "fulfilled time" in which the "Other" intruded into human space and time. Modernism arose because God visited Vienna.' By referring to Paul Tillich and other theologians and philosophers of religion, Whalen introduces a definition of religion that is so broad as to render it meaningless. To him, any emotional, spiritual, or intellectual utterance has to be seen as religious in essence, hence the famously 'subjective' culture of Vienna must have been religious. Since any form of human society has developed some form of religion, Whalen claims with reference to anthropologists like Tyler and Frazier, that religion must have played a central role when modernism was 'invented' in Vienna. Whalen is so convinced of this idea that he believes not only 'that one can do a religious reading of the Wiener Moderne; one can do a religious reading of anything. My point is that one must.' Where Whalen defines 'religion' too broadly, other key terms such as 'modernism' and 'modernity' are not defined at all. Instead we learn that the avant-garde - the producers of

Crisis of Identity: Culture and Society in Fin-de-Siècle Vienna (Cambridge, 1993; Steven Beller, Vienna and the Jews, 1867-1938: a Cultural History (Cambridge, 1989); Steven Beller, ed., Rethinking Vienna 1900 (Oxford, 2001); Edward Timms, Karl Kraus, Apocalyptic Satirist: Culture and Catastrophe in Habsburg Vienna (New Haven, Conn., 1986); Michael Pollak, Vienne 19oo: une identité blessé (Paris, 1992); Hermann Broch, Hugo von Hofmannsthal and His Time: The European Imagination, 1860-1920 (Chicago, 1984); Ilsa Barea, Vienna: Legend and Reality (London, 1966).

$4 \quad$ Steven Beller, 'Modern Owls Fly by Night: Recent Literature on Fin-deSiècle Vienna', in The Historical Journal 31, 3 (1988), pp. 665-683.

$5 \quad$ Robert Weldon Whalen, Sacred Spring. God and the Birth of Modernism in Fin-de-Siècle Vienna (Grand Rapids Mich., 2007).

$6 \quad$ Whalen, Sacred Spring, pp. 4, 7. 
modern culture - was an 'amazingly tiny group', and that most Viennese citizens were not part of it.

Whalen has little evidence to support his bold thesis. Surprisingly, we learn little about the role of religion in late Habsburg Vienna; large parts of the book do not mention religion at all. Instead, Whalen assumes the role of the omniscient narrator and provides the reader with anecdotes surrounding the most famous artists, intellectuals and academics of fin-de-siècle Vienna. No cliché is left untouched by Whalen; next to biographical sketches of the Viennese avant-garde, there are passages on the architecture of the Ringstraße, Viennese coffee houses, the Secession, and the Wiener Werkstätte. In addition, and for no apparent reason, we learn about the last members Habsburg family and the personal disasters they had to endure: the suicide of Crown Prince Rudolf, the assassination of 'Sissy', Franz Joseph's wife Elisabeth, and the failed marriage of Crown Prince Franz Ferdinand. Whalen repeats some of his stories, for instance that of Franz Ferdinand's troubled marriage and his characterisation of Hermann Bahr; on the other hand, there are surprising omissions: he refers to Sigmund Freud in passing only - he appears on page 132 for the first time; in a chapter on language we learn that psycho-analysis is a 'talking therapy' - where his view of religion would have deserved detailed analysis; Ludwig Wittgenstein is ignored completely. On the whole, Whalen adds little to our knowledge; it remains his secret how the material he has compiled can help to understand the religious underpinnings of fin-de-siècle Vienna. He does not engage properly with the large body of literature dedicated to fin-de-siècle Vienna that his study is meant to supersede. Steve Beller's works are completely ignored, as are other important studies on Viennese Jews, 7 and Jacques Le Rider's study on 'modernity and crisis of identity' is not mentioned either. Still, Whalen does not go beyond the standard themes of the existing literature on Vienna 1900 and has produced a very conventional cultural history. He refuses to draw conclusions from the material he has amassed, largely due to the dubious character of his main argument, and leaves the

7 Ivan Oxaal, Michael Pollack, Gerhard Botz, eds., Jews, Anti-Semitism, and Culture in Vienna (London, 1987); Marsha Rozenblit, The Jews of Vienna, 1867-1914: Assimilation and Identity. (Albany NY, 1984); Wistrich, Robert, The Jews of Vienna in the Age of Franz Joseph (Oxford, 1989). 
analysis to the reader. He does not tell us when exactly God visited Vienna and how his visit influenced fin-de-siècle culture and the development of modernism. Hence the study is a missed opportunity, in two ways. On the one hand, a new, comprehensive overview that synthesised the many specialised studies on Vienna 1900 would be very welcome. Such a study would need to include more than biographical sketches of the 'usual suspects', and it would need to tell us more about everyday life in Vienna by integrating the social, political and cultural history of the city. It should also compare Vienna to other European cities within and outside the Habsburg Empire. Secondly, it would have been highly interesting to find out how religion did influence the protagonists of the Viennese fin-de-siècle. A thorough study on religion and modernity would have added an important dimension to our picture of Vienna 1900, especially by looking at the role and influence of Catholicism and the Catholic Church in the late Habsburg era.

Deborah Coen's 'Vienna in the Age of Uncertainty', in contrast to Whalen, shows a way in which criticism of Schorske's seminal study can be productive and lead to important new insights into the culture of the Austrian middle-class and the history of liberalism in the Habsburg monarchy. ${ }^{8}$ By writing the history of science through the prism the Exner-Frisch family, a 'scientific dynasty' in nineteenth and twentieth century Vienna, she adds considerably to our understanding of Habsburg Austria, the culture of fin-de-siècle Vienna, and the relationship between the private and the public, between politics, science, and aesthetics in the modern era. She achieves this by questioning some of Schorske's assumptions about modernist culture as a form of compensation for the failure of liberalism: 'We will find a culture in which scepticism, far from being liberalism's downfall, was in fact its core value; a culture in which the family sphere was not a retreat from rational thought and political engagement but constitutive of them.'9

While Coen's general approach is not fundamentally different from the Schorske 'paradigm' - she has studied a family at the centre of the liberalacademic establishment of Vienna which over four generations produced a number of eminent professors in such diverse fields as philosophy, physics,

8 Deborah Coen, Vienna in the Age of Uncertainty. Science, Liberalism and Private Life (Chicago, London, 2007).

9 Coen, Vienna in the Age of Uncertainty, p. 2. 
medicine, law, biology, and history - she takes issue with some of Schorske's main 'dichotomies', 'between reason and uncertainty, publicity and privacy'. ${ }^{10}$ She describes a family atmosphere that was not marked by generational conflict, but by harmony, solidarity and tradition. To understand the scientific theories and educational policies of several members of the Exner family, Coen explains, knowledge of their private lives and hence a biographical approach is necessary: 'The Exners interwove domestic life and the life of science so tightly that it is impossible to understand one without the other. ${ }^{11}$ It was not rebellion against their liberal fathers' beliefs and values, but the conscious preservation and adaptation of received intellectual traditions that characterized the Exner family. Intellectual traditions were being passed on and kept alive from one generation to another. Similarly, Coen dismisses Schorske's idea of a retreat into the private sphere as the dual result of the failure of liberalism and generational conflicts: rather, Coen argues, the private sphere provided inspiration for creative ideas, and private experiences were translated into social-political ideas and policies. Coen can show how the liberal ideals of 'many-sidedness' (Vielseitigkeit) and independence of the person influenced educational reform in the Habsburg Empire, regardless of the decline of the liberal party at the end of the nineteenth century.

The 'founder' of the Exner family as a scientific dynasty was the philosopher Franz Exner who advised the Austrian government on reforming the curricula of secondary schools and universities in the 1840 s and whose ideas had a lasting impact on the educational system of the Habsburg Empire: 'Exner's real innovations lay in his program for the Gymnasium, since his program for higher education resembled what he had seen at the Prussian universities. For the first time in the history of these elite institutions in the Habsburg Empire, classes would be taught in local languages. Never before had German literature been deemed a worthy topic of study at Gymnasium, of equal value for Erziehung as the classics of Greece and Rome. Now there would be classes taught in languages from Magyar to Slovenian. [...] The ultimate goal of the Gymnasium now became not the mastery of particulars but the cultivation 
of a "noble character".'12 All ingredients of the family's socio-political views were present in Franz Exner's reform of the 1840s: the dual battle against religious dogmatism and political reaction, and probabilistic reasoning as the answer to these two enemies of the liberal middle-class. School reform remained a concern for members of the family; in the 1890s it was Emilie Exner who acted as an expert for the Ministry of Education, and Serafin Exner became rector of the university of Vienna in 1908 and thus 'recapitulated a historical as well as individual progression from certainty to doubt to probability.' 13

The concept that linked the Exners' political ideas with their academic and scientific work was the theory of probability. Faced with the dogmatism of the Catholic church on the one hand and scientific determinism on the other, the Exners developed a sceptical world view that did not lead to despair, frustration and the retreat from politics, but provided a means to counter scientific determinism and religious dogmatism. For the Exners, Coen maintains, theories of probabilistic truth were a way to deal with the uncertainties of the modern age when religion could no longer provide a stable basis. Doubts about 'last things' were not taken as a threat, but as a virtue. Coen argues 'that Austrian liberals made probabilistic reasoning into a virtue rather than an admission of defeat'. This attitude signified a specifically Austrian 'culture of uncertainty' that was 'related to and yet distinct from those that emerged elsewhere in Europe in the nineteenth century.'14 The concept of probability proved to be versatile and useful for both scientific and sociopolitical purposes; it could serve as an epistemological standard, a tool for quantifying the bounds of physical variability, and a model of mental function. The place where 'the bridge between the Exners' public and private lives' was built was not the thriving Austrian capital, but the family's summer retreat 'Brunnwinkl' on the Wolfgangsee near the Salzkammergut. Indeed, even though the study is dedicated to an important family clan of fin-de-siècle Vienna, the second home of the Exners at the foot of the Alps is the real 'star' of the book. While we learn fairly little about the changes in the city of Vienna, the transformation of 'Brunnwinkl' from a rural, alpine backwater into a popular 
summer resort where the urban elites would spend their holidays is described in detail.

By focusing on the Exner family, Coen's study provides a new perspective on some of the familiar episodes of fin-de-siècle Vienna. Josef Breuer, for example, Freud's early collaborator and co-author of the 'Studies on Hysteria', was a close friend of Sigmund Exner, one of Freud's teachers at the University of Vienna, who 'anticipated' the theory of sublimation. Coen uses the example of Sigmund Exner to challenge Schorske's view that the discovery of the unconscious - a collaborative achievement, not Freud's personal discovery was neither a cause for despair nor a threat to liberal rationality: 'To the contrary, Exner's model of the reasoning mind fully encompassed the limitations of consciousness. Reasoning meant working within this framework of the accidental and unpredictable. For Exner, the mind was a hunter, and therein lay its power. ${ }^{15}$ She also provides a new interpretation of another famous story of fin-de-siècle Vienna, the scandal about Gustav Klimt's paintings for the new building of the university that caused a stir among the academic establishment. Sigmund Exner was among the outspoken critics of Klimt's painting 'philosophy', but was not an aesthetic reactionary who demanded a return to Renaissance style. The position of the Exners and their colleagues in the aftermath of the Klimt scandal, Coen claims, has largely been misinterpreted: 'They have been painted as dogmatists and pedants, when in fact the version of rationalism they were defending was as self-consciously antidogmatic as it was hostile to the undisciplined subjectivity they saw in Klimt's mural.'16 For Serafin and Sigmund Exner, the idea of liberalism was closely tied to their scientific research, and was not indifferent to aesthetics. To them, liberalism depended on the 'possibility of speaking unambiguously about a shared world. This meant rendering language transparent, making experience universalizable, on the model of the mathematization of the natural sciences.' Thus, the political views of the Exners and physiological psychology were closely tied: 'Both projects depended on the cultivation of a certain observational 
attitude, one that was independent yet empathetic, sober but not unmoved by beauty - a realism, in short, modified by idealism.' ${ }^{17}$

One shortcoming of Coen's excellent study is the omission of the fourth generation of the Exner/Frisch clan from the main body of her text. Hans Frisch (Law), Karl Frisch (Biology), Robert Exner (Psychiatry) und Franz Exner (criminal biology, who acted as defence lawyer during the Nuremberg trials) all supported the Nazi regime, to varying degrees and for different reasons, but are only mentioned briefly in the conclusion to her study. A full discussion of their careers, political views and private lives would have opened a whole new set of questions, and would have raised some doubts about her criticism of Schorske's interpretation. Was there, after all, an affinity between the kind of liberalism that the Exners represented, and the Nazi regime? Why did their liberal ideas collapse so quickly in the face of fascism? Despite this criticism, Coen's study is a major contribution to the study of liberal, middle-class Vienna and to the history of science. The range of topics she discusses is enormous, ranging from the school system and educational reform to theories of knowledge, from aesthetics to physical theories of colour, from meteorology to the 'language of the bees' and the beginnings of ethology, from law to art history. The Exners' liberalism, wedded to theories of probability in their dual fight against catholic dogmatism and scientific determinism, and their bourgeois family network, mainly located at the summer retreat in the Austrian Alps, provide the frame for the study. Thus we are presented with a rather different account of fin-de-siècle Vienna, a view from the centre of the respectable middle-class, not from the margins of bohemian coffee house culture, which urges us to reconsider a number of assumptions that are based on Carl Schorske's interpretations and have rarely been questioned.

Maureen Healy argues against the Schorskean paradigm from a different perspective: She has written the history of the collapse of the 'world of yesterday' in Vienna during the First World War . She takes issue with the implicit elitism of cultural histories of fin-de-siècle Vienna and employs the perspective of the social historian to remind the reader of the social realities of the modern metropolis: 'Vienna was a city of two million residents, the vast majority of whom did not read Hofmannsthal and were not patients of Freud. 
This study introduces a different cross-section of Viennese society, in which the key to understanding politics is not art, but food.' She presents her work as 'a case study of total war' that interprets 'the social disintegration of the Habsburg Empire from the perspective of everyday life in the capital city' and argues that 'the city fell before the state collapsed in a military and diplomatic sense in the autumn of 1918'. Contrary to expectations of a national catharsis through the war effort that would heal the wounds of national conflict, Healy argues, the experience of war in Vienna was not a 'coming together' but a complete falling apart of the established social and moral order. ${ }^{18}$ Her study is divided into two main parts, the first one looking at 'Politics and Representation', the second at 'State and Family', which 'together tell the story of the social disintegration of the Viennese home front'. Her main sources are letters, police reports, government documents, the daily press and other contemporary publications, insofar as they tell us about the view from below and the experiences of common people; she is faced with the usual problem of such a perspective since her source material has been selected 'from above', by civil servants, policemen, newspaper editors, and archivists. The first chapter analyses in detail the problems of supplying Vienna's large and growing population with food during the war. According to one contemporary observer, 'food had come to dominate the collective psyche of wartime Vienna'.19 Food supply in Vienna during the war was worse than in any other European city, including Berlin, and rationing of basic foodstuffs was introduced as early as 1914. Healy argues that, in contrast to official propaganda, the sea blockade was not the main reason for the dismal supply, but that this was a home-made problem: Hungary, before the war the main supplier of agricultural goods, cancelled arrangements that had been in place since the settlement of 1867 and reduced her agricultural supplies to Vienna significantly, and Galicia, the main agricultural resource in Cisleithania which had become a main battlefield on the Eastern front, did not produce the required amounts of food anymore. The miserable supply of food undermined all appeals by politicians to national solidarity and endurance and turned Vienna into an extended state of emergency, characterised by denunciations, suspicion, lining-up for food, and ultimately food riots. 'Normal' and everyday Life in World War I (Cambridge, 2004), p. 21, 3-4. 
society had all but disappeared by 1917: 'If we compare these incidents [food riots] to the "workers" strikes of 1918, which historians have pinpointed as a crucial turning point in wartime domestic politics, we see that Viennese food rioters had in fact set the stage and shaped the discourse of Viennese politics.'20 Healy then takes a look at culture 'from below', that is, attempts by the government to distract the population from the dire material conditions and improve public morale by means of propaganda and entertainment. She first charts the changes to entertainment in the city, above all the cinema, during the war and analyses the War Exhibition held in Vienna in 1916. This exhibition formed a 'Disneyland-like theme park' that covered an area of 50 ooo square metres at the Prater fairground, representing the largest war-related entertainment event in Europe and a 'showcase for [the] marriage of propaganda and entertainment'. ${ }^{21}$ Given the problems of providing even the most basic foods, the effort put into the exhibition is astonishing. The last chapter of the first part is devoted to censorship and denunciations. Next to food, Healy argues, 'information was the most politicized commodity on the home front. It was produced, traded and regulated like a commodity, and aimed, delivered and feared like a weapon.' The state put most of its efforts into censorship and control of public opinion and left 'positive' propaganda to the Catholic Church and Vienna's German-language press. The 'instability and unreliability of circulating information' encouraged both the spread of rumours and the practice of denunciation, leading to a 'crisis of truth in Vienna that contributed to the dissolution of social relations at the local level.'22 In contrast to other studies of state censorship, Healy stresses the limits of the system, not least because of the large number of languages used in the Habsburg capital and a general inefficiency of state institutions.

The second part of Healy's study looks at the situation of women, children, and men in war-time Vienna. She decribes the discrepancy between official attempts to appeal to the solidarity of all women during the war and the persistence of class differences between women. According to Healy, the war did not create 'unity' amongst women, but increased prejudice and hatred, for instance the anti-semitism of Christian-Social women. Again, it was the concern 
for the most immediate material needs that prevented female solidarity during the war: 'Individual women in the venues of everyday life practiced a different sort of politics, undermining theories of universal feminine virtue under the noses of the organized women who advocated them. War brought out human traits - greed, anger, aggression, jealousy and selfishness - that did not fit within the theoretical rubric of the feminine.'23 The state, with the help of the local press, tried to include Vienna's children in the mobilization of the home front and used stories of child heroes to strenghten the morale of the population and appeal to their willingness to sacrifice. However, with the material situation in the city deteriorating during the course of the war, the majority of children in Vienna were malnourished, became delinquent and suffered from general neglect in a 'fatherless society'. The men that were left at the home front became a minority within urban society, comprising of those too young or too old for conscription, and those whose professions exempted them from front service. The latter increasingly became the targets of criticism and were suspected of being 'shirkers' and not contributing to the Austrian war effort. In her conclusion, Healy strongly supports the interpretation that the Habsburg Empire collapsed at the end of the First World War because of internal reasons. The state of emergency that the prolonged war created at the home front sharpened problems and conflicts that had existed before. According to Healy, it was not only the national conflicts that destroyed the Empire, but the complete collapse of 'normal' social relations. Healy has produced a meticulously researched study of war-time Vienna that makes an important contribution to the history of the Habsburg Empire as a whole.

David M. Vyleta's study belongs to the literature of fin-de-siècle Vienna in an indirect way. His starting point is the Hilsner trials, one of the notorious blood libel cases in Central Europe around the turn of the century; his main interest, however, lies in the workings of the modern media, that is largecirculation, popular newspapers, as essential ingredients of modern urban culture. ${ }^{24}$ Hence he focuses on the reports about the trials in the Viennese press, not the court proceedings themselves that were held in Bohemia. Vyleta's main thesis is that the Hilsner affair was first and foremost an event constructed and

23 Healy, Vienna and the Fall of the Habsburg Empire, p. 209-210.

24 David M. Vyleta, Crime, Jews, and News. Vienna 1895-1914. (New York, Oxford, 2007). 
manufactured by Viennese newspapers. The example of the Hilsner trials serves to highlight a number of related, more wide-ranging questions that reach far beyond the history of antisemitism in the Habsburg empire: 'What exactly was the contemporary conception of criminality? Where were popular narratives of crime articulated, and what were the generic rules of this articulation? How far did popular and scholarly conceptions differ? How did antisemitism interact with the language of crime?' By tackling these questions, Vyleta aims to contribute to a 'neglected chapter of the history of modernity.' 25 The rather awkward title of the book is explained by his interest in the interrelated histories of antisemitism, in Vienna and the Habsburg empire more generally, criminology, and the emerging mass media.

Vyleta can show that criminology in the style of Cesare Lombroso was much less influential in Habsburg Austria than is assumed in a number of academic studies, a finding that is supported in the case of Berlin by Philipp Müller's recent study. ${ }^{26}$ Not Lombroso's criminological typologies were applied in court cases, but rather 'criminalistics' as developed by Hans Gross, a former judge and state prosecutor who became influential as Professor at the university of Graz. Gross was openly opposed to Lombroso and his deterministic approach and instead championed meticulous empirical research as the 'craft' of the prosecutor. Based on this finding, Vyleta takes issue with Sander L. Gilman's view that the stereotype of 'Jewish Criminals' was a main ingredient of antisemitic ideology in the German-speaking lands. Vyleta holds that the 'parallels between criminal and Jewish stigmata' that Gilman has found 'function solely on the level of analogy'. The language of anthropological difference 'was not in any way owned by anti-semites', hence 'Gilman's thesis that to some degree Lombrosite criminal stigmata and contemporary antisemitic discourse approached each other in the period under discussion is not brought out by the evidence. It works much better if one considers the scholarly treatment of Gypsies rather than Jews.'27 In his detailed analysis of

$25 \quad$ Vyleta, Crime, Jews, and News, p. 2.

26 Philipp Müller, Auf der Suche nach dem Täter: Die öffentliche Dramatisierung von Verbrechen im Berlin des Kaiserreichs (Frankfurt/Main, 2005).

27 Vyleta, Crime, Jews, and News, pp. 46, 53. See Sander L. Gilman, The Case of Sigmund Freud. Medicine and Identity at the Fin-de-Siècle (Baltimore MD, 1993). 
court reporting in Viennese newspapers - Vyleta refers mainly to mass circulation papers, but uses some quality publications for comparison - he can show the similarities between court reporting and Hans Gross' 'criminalistics' with its focus on gathering circumstantial evidence. Criminological typologies, on the other hand, were not referred to in newspapers.

Vyleta reminds us that a 'yellow press' could develop in Vienna only after 1900 , with the relaxation of censorship laws and the lifting of special taxes on advertising. The new mass papers presented criminal trials as 'public theatre' and spectacle - appropriately in the capital of German theatre - using language and forms of display that large audiences were familiar with. He discusses 'a series of sensations that were explicitly built up as Jewish crimes by antisemitic papers' and explains that the antisemitic press in Vienna frequently and regularly reported on Jewish crimes, the majority of which were alleged or genuine business crimes. Sexual and violent crimes committed by Jews were much less frequent, to the chagrin of the antisemites, since 'reports on Jewish violent crimes were harder to manufacture than any other form of crime as all contemporary crime statistics confirmed: Jewish involvement in violent crime was exceptionally rare.' In its reports, the antisemitic press used specific strategies of constructing 'Jewish crimes': it presented the Jewish defendants as 'rational and cunning, and systematically criminalising other Jews surrounding the trial (lawyers, police-man, spectators, journalists, witnesses, psychiatrists) by charging them with truth distortion'. Jewish crimes were thus presented as 'crimes against the justice system itself, and, by extension, against society'. ${ }^{28}$ The use of an antisemitic vocabulary, Vyleta argues, identified papers politically and could not be used casually; the antisemitic press was clearly separated from other newspapers. Therefore, Vyleta argues, the thesis that antisemitism had become 'respectable' in Vienna before the First World War needs rethinking.

In the central chapter of his study, dedicated to the press coverage of the Hilsner trials, Vyleta challenges the explanation Helmut Walser-Smith has provided for the seemingly archaic accusation of ritual murder made against Jews in modern times: "Whatever "script" ritual murder accusations followed, [...] it had not - as Helmut Walser-Smith maintains - been acquired and retained in the collective memory over centuries of ritual repetition, but was 
absorbed in the very contemporary language of the modern trial report and as such was contingent on the existence of modern mass media and the high rates of literacy typical for the modern era.' Vyleta maintains that, first of all, the Hilsner trials were a 'media creation'; its origins can be traced to the two antisemitic publishing houses in Vienna and Prague that were actively involved in pursuing the 'story'. Without the efforts of the Viennese Volksblatt's active, investigative journalism, there would not have been a trial, Vyleta argues. The accusations of 'ritual murder' 'did not simply arise from rural antisemitic convictions or Czech national politics'. Rather the 'strange alliance between German anti-semites with anti-Czech and pan-German attitudes with an antiGerman Czech antisemitic agitator' made sure that 'the Polná murder became the biggest news story of the year throughout the empire and beyond'. 29 In his detailed analysis of the reports from the two Hilsner trials Vyleta can show that only the explicitly antisemitic press endorsed the story of ritual murder. The coverage of the Hilsner trials confirms his analysis of other types of 'Jewish' crime; not Hilsner's 'potential pathological deviance' was highlighted in the press, but 'the details of both investigation and court-room events'. The antisemitic press charged 'the ideological enemy with the distortion of truth and influencing the course of justice'.30

Vyleta draws conclusions that contradict some of the received wisdom about antisemitism as a 'cultural code' in fin-de-siècle Vienna and Central Europe at large. 'Neither physical nor psychological criminal stigmata were mapped onto Jewish bodies and minds,' Vyleta claims. In an intellectual atmosphere that was intrigued by theories of degeneracy, it would have been an easy task 'for antisemitic scientists to mark Jews as a degenerate race and hence driven to deviance'. Instead, the majority of antisemites chose a different option which was in line with another mainstay of modern antisemitic ideology: they stressed the 'Jews' vitality in the modern world' in contrast with 'the difficulties many others in the population were experiencing in adjusting to modernity's demands'. ${ }^{31}$ Vyleta is adamant that his findings are not meant to belittle the

29 Vyleta, Crime, Jews, and News, p. 180-81. See Helmut Walser Smith, The Butcher's Tale: Murder and Antisemitism in a German Town (New York: 2002). Walser Smith has studied the 'Konitz Affair' in East Prussia. Vyleta, Crime, Jews, and News, p. 203.

$31 \quad$ Vyleta, Crime, Jews, and News, p. 221. 
extent to which antisemitism had spread within Viennese society at the turn of the century, but he maintains: 'All that can be stated with certainty is that, of all the people enjoying their daily dose of crime in the papers, only those who identified themselves as antisemites by their choice of newspaper would come across any narrative of Jewish crime. For everyone else - i.e. the vast majority of the population - this narrative did not exist.' 32 This is a welcome reminder to be careful in drawing conclusions about the degree and extent of antisemitism within Vienna with the hindsight knowledge of the history of the Third Reich and the shoah.

Thomas Weyr has written a political history of Vienna during exactly that period, from its integration into the Nazi empire in 1938 to the end of the Second World War.33 Using mainly the contemporary press as sources, he provides a detailed chronological account of the events of the 'Anschluß' of Austria, the political violence that accompanied it, and the increasing levels of persecution of Vienna's Jewish population. Without a proper introduction, the chronological narrative is only interrupted by chapters on the political history of Austria in the interwar years and on 'Vienna's Golden Autumn', the city's cultural history from 1867 to the 'Anschluß'. The final chapter consists of a summary of Austria's post-war history up to 2004. In an effort to make his detailed accounts of political history easier to digest, Weyr has included personal stories of individuals who suffered from Nazi rule in Vienna, based on interviews and personal recollections, including the author's own memories of his childhood in Vienna. The book is a cross between a strictly chronological political history that follows events day-by-day, sometimes even hour-by-hour, and a collection of eyewitness accounts. Weyr uses published memoirs and diaries where available, but he does not indicate how he selected the eyewitness accounts; apparently, we are presented with a randomly chosen sample of recollections by his acquaintances. Weyr has wasted no thoughts on the problems of oral history, which diminishes the value of his study. The book offers a wealth of detailed information and synthesizes some of the specialized literature, but it does not include a survey of this scholarship. The best sections of the book are on the increasing level of persecution and destruction of the

$32 \quad$ Vyleta, Crime, Jews, and News, p. 224.

33 Thomas Weyr, The Setting of the Pearl. Vienna under Hitler (Oxford, 2005). 
Jews of Vienna, and more generally on everyday life in Vienna during the war. Weyr's study might serve as a starting point for further research, but, quite typically for historical books written by journalists, lacks an overall thesis. This is a pity since detailed studies of major German cities during the Third Reich (for instance on Berlin, Munich, Hamburg, Cologne) are rare or do not exist at all, and the example of Vienna could have made for an excellent case study. Chad Bryant's recent history of Prague could serve as an example and role model for future studies of cities under Nazi rule. 34

Cathleen M. Giustino's study of the 'assanation', the tearing down and rebuilding of Prague's historic Jewish quarter is a an example of conventional urban history. The study is based on an impressive range of primary sources and relevant research literature. 35 While introducing the history of local government in Prague in the context of the late Habsburg Empire, Giustino also uses her case study to shed light on the history of Czech nationalism, liberalism, and antisemitism during that period. She explains the system of 'municipal autonomy' and where it reached its limits, due to a strong dependency on the Imperial government in Vienna. For instance, the city council needed the approval of the emperor in important decisions such as the election of mayors or large building projects. In local elections, the curia-system was used; hence, very few of Prague's citizens qualified to vote. This voting system and the dwindling influence of Prague's German-speaking community guaranteed the dominance of the Czech liberals in local politics, and the city became a main stage for the struggle between 'Old' and 'New Czechs'. Surprisingly, the study of antisemitism in Prague does not feature prominently in Giustino's book; she even refuses to use the term 'antisemitism' and speaks of 'anti-Judaism' throughout the book even where the antisemitic views of her protagonists are beyond doubt. Jan Neruda's antisemitic writings for instance, typical of a strong current within Czech society, are mentioned, but not analyzed. Karel Baxa, as one of the main champions of the regeneration of Josefov, the old Jewish quarter of Prague, would deserve a biographical study in its own right, given his 
role in the 'sanitation' of the old Jewish quarter, as state prosecutor during the Hilsner trials, and as mayor of Prague from 1918 to 1937.

The plan to tear down the old Jewish town just north of Prague's city centre was pushed by the emerging medical establishment of the rapidly growing city. The medical lobby took the appalling living conditions in the overcrowded neighbourhood as an argument to call for the rebuilding of the area; at the same time, it used this instance to make the case for establishing a municipal public health administration. Giustino illustrates the poor living conditions in Josefov before the regeneration with individual case studies and thus includes some interesting details on everyday life in Prague before the First World War. She can show how concerns about public health, open or disguised antisemitism, Czech nationalism and the rhetoric of progress all combined to make a major and expensive building project possible; the enormous cost of the redevelopment of Josefov left the city of Prague heavily in debt for years. A rather unlikely alliance argued in favour of the large-scale regeneration project: the Czech liberals, both 'Old' and 'New', were eager to modernize the city and lift it to 'world standards', their eyes fixed on foreign commentators; the medical establishment campaigned for hygienic living conditions and a professional public health system; and the Jewish middle class saw the tearing down of old Josefov as a chance to end the segregation of Jews in the city and thus 'complete' their emancipation. Against these champions of redevelopment stood the critics, some of whom saw sinister foreign influences at work which were trying to destroy Czech characteristics by importing foreign architecture. Especially the straight streets of the new Josefor were despised as foreign, whereas the bends and curves of baroque Prague were celebrated as essentially Czech. The residents of Josefov, however, who were most immediately affected by the redevelopment and would lose their homes as a consequence, had no voice in the city council or in public debates and were largely neglected. Building works began in 1896 with the move of the first residents and the tearing down of houses; only the owners of the (rental) houses received compensation, former tenants were left to their own devices and had to find new flats on their own. Thus former tenants of Josefov became the real victims of the regeneration of their neighbourhood. Giustino can therefore highlight one of the main shortcomings of traditional liberalism, not only in the Czech lands: There was little sense of social justice on the part of the liberals, the fate of the 
working class was not considered seriously. On the whole Giustino has written a thorough study that would have profited from more context and analysis and less detail. Extended quotations from the minutes of the city council, the local press, clubs and associations show how well G. is informed about her subject, but are not always necessary to support her argument.

II.

A well-established 'paradigm' within which to study the history of Berlin, similar to Schorske's interpretation of fin-de-siècle Vienna, does not exist. But where Vienna before the First World War is looked at as the 'birthplace' of modernism, Berlin in the 1920 s is considered to have succeeded the Habsburg capital. With the founding of the Weimar Republic, Dorothy Rowe claims, 'Berlin had established its ground as the largely undisputed capital of European culture' ${ }^{6}$ Joachim Schlör's study on 'the ego of the city' focuses on the German capital and provides an example of how intellectual historians study urban history. He tries to re-construct the development of the stereotype of the 'City Jew' (Großstadtjude), of the Jews as quintessential city-dwellers, and uses Berlin as his main example. $37 \mathrm{He}$ traces the origin of the stereotype in question back to the beginning of the emancipation of the Jews in Prussia in the 1820s, but his main starting point is an unpublished text by Moritz Goldstein, written in 1938 and entitled 'A City for the Jews'. Goldstein was a German-Jewish journalist who had become famous with the so-called 'Kunstwart'-debate in 1912 when he published an essay entitled 'Deutsch-jüdischer Parna $\beta$ '. This essay caused a stir because it raised serious doubts about the possibility of Jewish assimilation into German society, contradicting the firm belief of the majority of German Jews while using ideas that sounded all too similar to those of the antisemites. In 1933 Goldstein was forced to flee from Berlin and settled in Palestine; his essay about the founding of a model city to solve the 'Jewish question' was written in Tel Aviv from a Zionist point of view.

Methodologically, Schlör tries to combine the perspectives of historians, cultural anthropologists, and literary critics in the field of Jewish Studies; in

36 Dorothy Rowe, Representing Berlin. Sexuality and the City in Imperial and Weimar Germany (Aldershot, 2003), p. 2. Joachim Schlör, Das Ich der Stadt. Debatten über Judentum und Identität, 1822-1938 (Göttingen, 2005). 
fact, large parts of his study read like a manifesto to promote an interdisciplinary approach in this field. He uses an astonishing, sometimes perplexing variety of texts: After a chapter on Goldstein, for instance, Schlör discusses the writings of Theodor Fontane, Wilhelm Ostwald (the mastermind of the collection 'big city documents' (Großstadtdokumente)), Alfred Döblin, Karl Scheffer and many others, without a clear indication of how exactly he has chosen these texts. Throughout the study, the review of research literature alternates with interpretations of historical texts. A cultural anthropologist by training, Schlör uses a consciously subjective style of writing which might irritate more traditional historians and social scientists. He also reveals a rather odd view of academic history, believing that source material that expresses 'opinions, feelings, and emotions' is not part of historical research in the strict sense, but belongs to anthropologists and literary critics. However, not only contemporary cultural historians, but also the most die-hard empiricists have always used personal, subjective texts such as letters, memoirs, diaries, and occasionally even fictional literature. Otherwise it would hardly be possible to write biographies, that most traditional of historical genres.

Despite its length, Schlör's study leaves many questions open. The introduction seems too long - it covers more than a fourth of the whole text but Schlör still comes back to discussing important analytical terms such as urbanization, Verstädterung, Bürgertum, and modernization in later parts of the book. A clear structure is lacking, as we are presented with a collection of Schlör's 'readings' that seems random at times. This lack of focus and structure is partly due to Schlör's interdisciplinary approach that he advertises continuously, partly to the fact that his study was originally submitted as a German post-doctoral dissertation (Habilitationsschrift) at the University of Potsdam: one gets the feeling that the main audience Schlör was writing for was not the general academic public but the faculty that had to examine the book. Another problem of the study lies with the concept of a 'stereotype'. Here Schlör has put surprisingly little effort into reflecting upon the function and uses of stereotypes, both in literature and in everyday practise. He believes that stereotypes such as the image of the 'city Jew' 'create themselves', independent of 'empirical facts'. For Schlör, stereotypes are merely prejudices that can be proven wrong by providing 'facts', a rather simple view for an intellectual 
historian. ${ }^{8}$ A more complex understanding of stereotypes could have explained their longevity and their adaptability to changing historical circumstances, and a more thorough contextualisation of his source material could have prevented Schlör from being surprised that the stereotype of the Jewish city-dweller was not only used by antisemites, but also by Zionists, including his hero Moritz Goldstein. Schlör's astonishment about finding the stereotype of the 'city Jew' both in antisemitic and in Zionist texts reveals another shortcoming: he underestimates the similarities between antisemites and Zionists regarding their general attitudes towards nations, nationalism and society. He considers the parallels between Zionism and urbanism to be remarkable, but presents this as a result of his studies when it should have been a starting point. The book as a whole seems unfinished and largely unedited; there are far too many, overlong quotations from historical texts and contemporary literature. Schlör lets these texts 'speak for themselves', and leaves their interpretation to the reader. On the whole, less could have been more; if Schlör had stuck to interpreting his main text, Goldstein's 'A City for the Jews', and studied it from a multitude of perspectives (biographical, ideological, historical, philosophical), we would have been presented with a more coherent and convincing monograph on an important topic.

In 'Representing Berlin', Dorothy Rowe investigates another important image of the city that developed during the rapid growth of the German capital into a 'world city'. Her aim is to provide 'an investigation into how the image of Berlin within discourses of modernity after 1896 and before 1930 becomes inflated with an image of a sexually voracious and devouring female who comes to symbolize the city's modernity'. In 1896 Berlin hosted a trade fair (Gewerbeausstellung) in an attempt to celebrate the technological and commercial developments of the city after the unification of Germany in 1871. Rowe takes this event as the starting point for her study, as one of three case studies. She intends to 'pursue a critique of modernist constructs of modernity and the city in which notions of female pleasure, desire and subversion are not accounted for.' 39 The first chapter on the trade fair includes a discussion of images of the city in contemporary texts by authors as diverse as Ferdinand 
Tönnies, Max Weber, Friedrich Naumann, Theodor Fritsch, and the 'conservative revolutionary' Oswald Spengler. The chapter provides a lot of interesting detail on contemporary debates about the city in Imperial Germany, but does not back her bold thesis about the sexualisation of images of Berlin. A short second chapter looks at the writings of Georg Simmel, the 'founding father' of cultural sociology whose essay on the City and Mental Life has become a classic in the field. Simmel is of particular interest to Rowe not only because he wrote an essay on the 1896 trade fair, but also because his main work focused on the contemporary modern city as the location where processes of modernization could be observed, and because he considers the consequences of these for gender relations. The second case study is an investigation of the 'Großstadtdokumente', a series of reports on urban life edited by the journalist Hans Ostwald from 1905 to 1908 . Here Rowe finds a lot of material with which to discuss the transforming roles and positions of women in the new world city Berlin, not least because of Ostwald's interest in the urban underworld, in nightlife, prostitution and crime in the German capital. The series also included the famous study by Magnus Hirschfeld on homosexuality in Berlin entitled 'The Third Sex'.

The last chapter of Rowe's short monograph pays tribute to the 'iconic turn', and focuses on German paintings depicting life in Berlin. As a trained art historian, Rowe seems finally at ease with her topic and concentrates on the paintings of Ernst Ludwig Kirchner, George Grosz, Otto Dix and others which provide her with ample proof of her main thesis; indeed, it seems, that their depictions of Berlin prostitutes, sex murder, and urban degeneration have inspired this very thesis in the first place. Berlin had become a representation of modernity with all the fears and desires this involved, 'and as such it had become embodied in the figure of a sensuous woman'. Not all of the material Rowe has studied does explain if and why Berlin became 'positioned as feminine during the Weimar era', however. ${ }^{\circ 0}$ Rowe tends to substitute analysis with postmodernist catchphrases; without any hint of irony, we learn that Berlin allowed its inhabtants to 'transgress the boundaries' of sexual conventions set up by bourgeois moral standards; 'spatial practises' are 'renegotiated', 'gender identities' become 'fluid'. Despite the use of this kind of terminology, the 
conclusions Rowe draws from her reading of Ostwald's 'documents' and the paintings of the Neue Sachlichkeit seem somewhat under-complex. For instance, the graphic violence in paintings by Grosz and Dix, especially of sexual murders, are accounted for as consequences of the 'specific socio-economic, historical and cultural changes that occurred during the Weimar Republic that played a crucial role in this defensive representational strategy'. ${ }^{41}$ The material Rowe has studied would have allowed more sophisticated interpretations, more limited and more wide-ranging at the same time. We are left with little that is new on Berlin during the 'roaring twenties'.

Despite the range and number of recent studies on Berlin and Vienna in particular, some gaps in the literature continue to exist. Berlin has been established as the 'paradigm' for the awkward modernity of the twenties, whereas Vienna is studied mainly, in the wake of Carl Schorske, as the unlikely cradle of modern culture in the pre-war fin-de-siècle. It seems timely to turn this perspective around and study the fin-de-siècle in Berlin more closely while concentrating on Vienna in the interwar period. Similarly, more detailed studies of both cities during the Third Reich would be very welcome. Also, studies that look at the 'lesser cities' in Germany, especially Munich, Dresden, Hamburg, Cologne, and Frankfurt, in comparison to Berlin, and of Budapest, Prague, and Krakow in comparison to Vienna, would add to our knowledge of urban modernity in Central Europe, which is more characterised by de-centralised networks of cities than the highly centralised Western nations of France and Great Britain. Studied in this way, cities can provide an alternative to the study of nation-states and can serve to integrate local, transnational and international history. The study of modern culture needs to take into account the high mobility of professional elites - entrepreneurs, engineers, artists, academics who moved frequently between cities and influenced the physical appearance and the intellectual atmosphere of these urban centres. Viennese architects, for example, commissioned work all over the Habsburg Empire, and the Bauhaus school in Berlin and Dessau can be viewed as a transnational institution as such.

The history of urbanisation is a central event in the history of modernity. Especially in the Central European capitals of Berlin and Vienna, where 
modernisation and urban growth started later and then advanced quicker than in West European cities, all aspects of social, political, economic, and cultural modernity and its consequences can be observed in detail. Vienna and Berlin were the places where 'everything that was solid melted into air', where society changed at a breath-taking pace, due to mass migration, social differentiation, technological developments, political radicalisation, and cultural innovation. There is no one best way to study the history of cities and urbanisation. To capture these simultaneous processes, which are all essential to an understanding of the dramatic impact of industrial modernity on Central European societies, an eclectic approach is necessary. Therefore, the study of cities should not be mistaken for local history, it encompasses much more than the history of municipalities. It makes it possible to study processes of modernization eye-to-eye and more precisely than on a national level. Therefore urban history is too important to leave to urban historians. 